\author{
Research Article
}

\title{
PRE AND POST TEST CLINICAL STUDY TO ASSESS THE COMBINED EFFECT OF BRIHATYADI KSHEERA KASHAYA, CHANDRAPRABHAVATI AND SHWETA PARPATI IN URINARY TRACT INFECTION
}

\author{
Anjana.S ${ }^{*}$, Mahesh.C.Kundagol'1, Devipriya Soman², James Chacko ${ }^{3}$ \\ ${ }^{*}{ }_{1}$ Associate Professor ${ }^{2}$ Assistant Professor, ${ }^{2}$ Professor and Head, Department of Kayachikitsa, Amrita School of \\ Ayurveda, Amritapuri, Amrita Vishwa Vidyapeetham, Kerala, India.
}

\begin{tabular}{l} 
Article info \\
\hline Article History: \\
Received: $30-04-2021$ \\
Revised: $01-05-2021$ \\
Accepted: $24-07-2021$ \\
Published: $16-10-2021$
\end{tabular}

\section{KEYWORDS:}

UTI,

Brihatyadiksheera

kashayam,

Chandraprabahvati,

Shwetaparpati,

Mutrakruchra.

\begin{abstract}
Purpose: UTI is the broad term used to describe infection of any part of urinary tract and is a problem frequently encountered by health care providers today. E.coli is found to be the main causative agent for causing UTI (80\%). The prevalence of UTI are increasing and the present standard of care includes the usage of antibiotics. The alarming and exponential use of nonspecific antibiotics, increased resistance and the high cost of prescribed medications for the management of the infective microorganisms will raise the need for alternate and safe medication. The signs and symptoms of Mutrakruchra and UTI are similar in nature. The combination of Brihatyadi Ksheera Kashaya, Chandraprabhavati and Shweta Parpati is widely practiced in Mutrakruchra. The present study was aimed at exploring the combined effect of the above combination in UTI.

Materials and Methods: The present study was a single group study with pre and post test study design. 20 diagnosed cases of UTI based on ICD10N39.0 diagnostic criteria and proper exclusion were selected from IPD and OPD of Amrita Ayurveda Hospital. They were administered Brihatyadi Ksheera Kashaya, Chadraprabhavati and Shweta Parpati for 15 days.

Result: The obtained data were analyzed statistically with symptoms of UTI, Urine analysis and urine culture by using Wilcoxon signed rank test done on the $0^{\text {th }}$ and $16^{\text {th }}$ day. There was significant change with $100 \%$ of improvement in clinical symptoms of UTI after treatment. Statistically significant result was obtained in reduction of WBC with $p$ value 0.001 , Epithelial cells with p value 0.005, and Nitrites, Leucocyte esterase, Bacteria with $p$ value 0.0001 . There was reduction in growth of E.coli in urine culture with statistically significant $\mathrm{p}$ value 0.0001 . Conclusion: The combination of Brihatyadi Ksheera Kashaya, Chandraprabhavati and Shwetaparpati is effective in UTI.
\end{abstract}

\section{INTRODUCTION}

Urinary tract infection is associated with multiplication of organisms in urinary tract and is defined as the presence of $>10^{5} \mathrm{CFU} / \mathrm{ml}$ in the midstream sample of urine. The term UTI covers a range of conditions of varying severity from simple Urethritis and Cystitis to Acute pyelonephritis with septicaemia[1].

\begin{tabular}{|l|l|}
\hline \multicolumn{3}{|c|}{ Access this article online } \\
\hline Quick Response Code & \begin{tabular}{l} 
https://doi.org/10.47070/ijapr.v9i9.1870 \\
\hline
\end{tabular} \\
\hline
\end{tabular}

In majority of UTIs bacteria establish infection by ascending from the urethra to the bladder. The most common pathway for renal parenchymal infection is the further ascent of bacteria to the kidney[2]. Bacteria causing UTIs will colonize the colon or perianal region and periurethral region which forms a biofilm that usually resists the body's immune response[3]. Infections of the urethra and bladder are often considered superficial or mucosal infections and the Pyelonephritis and renal suppuration signify tissue invasion. Women are particularly at risk of developing UTIs because of shorter urethra. 50 to $80 \%$ of women have at least one UTI during their life time. E.coli is found to be the main causative agent for causing UTI (80\%). ${ }^{[4]}$ Urine is an excellent culture medium for bacteria and the Gold standard for diagnosis of UTI is 
urine culture. The prevalence of UTI is increasing and the present standard of care includes the usage of antibiotics which are having limitations due to increased resistance.

The signs and symptoms of Mutrakruchra (Vatapittadhikya) and UTI are similar. Mutrakruchra is one of the main disease among Mutravikaras which comes under Mutraapravartija roga[5]. Ayurveda has given prime importance to Mutravahasrotovikaras and its management. The combination of Brihatyadi Ksheera Kashaya, Chandraprabhavati and Shweta Parpati is widely practiced in Mutrakruchra. The present study was aimed at exploring the combined effect of above combination in UTI.

\section{METHODOLOGY}

\section{MATERIALS AND METHODS}

\section{Source of Data}

The patients who attended the OPD and IPD of the Amrita Ayurveda Hospital, Vallikkavu, Karunagapally, Kerala, with signs and symptoms of UTI were screened. Among these, 20 patients who fulfilled the inclusion criteria were included in the study.

\section{Inclusion Criteria}

- Patients of either gender of age between 20 to 70 years.

- Presence of significant bacteria in urine

\section{Treatment Schedule}

Table 1: Table showing details of Therapeutic Intervention
- Patient diagnosed with UTI as per ICD10 N39.0 diagnostic criteria

\section{Exclusion Criteria}

Diagnosed case of:

- Nephrolithiasis

- Candidiasis of urinary tract

- Pregnancy

- Renal failure

- Liver failure

- Foreign body in urinary tract

- Instrumentation of urinary tract

- Pyelonephritis

- Hydronephrosis

\section{Study Design}

It was a single group clinical study with pre and post test study design.

\section{Source of Medicine}

Brihatyadi kashayachurna was prepared at GMP certified pharmacy of AV Oushadhashala, Thattarkonam, Kollam-5, and Kerala state -691005 Chandraprabhāvați was purchased from the GMP certified pharmacy, Amrita life. Shwetaparpați was prepared in the Department of Rasasastra and Bhaishajya kalpana, Amrita school of Āyurvēda

\begin{tabular}{|c|c|}
\hline $\begin{array}{l}\text { From } 1^{\text {st }} \text { day to } \\
15^{\text {th }} \text { day }\end{array}$ & $\begin{array}{l}\text { The Following internal Medicines was given: } \\
\text { - Brihatyadi Ksheera Kashaya } 50 \mathrm{ml} \text { twice daily, before food } \\
\text { - Chandraprabhavati }(600 \mathrm{mg} / \mathrm{tab}) \\
\text { - } 2-0-2 \mathrm{BD}(\text { Before food) } \\
\text { - Shwetaparpați }(500 \mathrm{mg}) \text { with } 2 \text { litre of water in divided dose } \\
\text { frequently }\end{array}$ \\
\hline
\end{tabular}

\section{Assessment}

Subjective parameters are painful micturition, urinary urgency, frequency, burning micturition, tiredness, nausea and back pain.

Objective parameters are WBC, epithelial cells, nitrites, leucocyte esterase, bacteria and urine culture.

\section{Statistical Analysis}

Completed 20subjects were taken for statistical analysis. Wilcoxon signed rank test were used for statistical analysis of the collected data.

\section{OBSERVATION AND RESULT}

Out of the 20 subjects of UTI studied in the research, $75 \%$ of subjects were under the age group between 20-29 years. 95\% subjects were females and 5\% of the subjects were males respectively. Sixty percent of subjects were married, and $40 \%$ was unmarried. The maximum number i.e., $90 \%$ were taking mixed diet and $10 \%$ were taking vegetarian diet. The study revealed that $20 \%$ had previous history of UTI and $95.0 \%$ had Irregular appetite and $5 \%$ had regular appetite. 


\begin{tabular}{|c|l|c|l|c|}
\hline S No & Variables & Mean BT & Mean AT & $\begin{array}{l}\text { Percentage of } \\
\text { Improvement }\end{array}$ \\
\hline 1 & Painful Micturition & 0.95 & 0.05 & $94.7 \%$ \\
\hline 2 & Urinary Urgency & 0.8 & 0 & $100 \%$ \\
\hline 3 & Frequency & 0.95 & 0 & $100 \%$ \\
\hline 4 & Burning Micturition & 0.7 & 0 & $100 \%$ \\
\hline 5 & Tiredness & 0.2 & 0 & $100 \%$ \\
\hline 6 & Nausea & 0.2 & 0 & $100 \%$ \\
\hline 7 & Back pain & 0.55 & 0 & $100 \%$ \\
\hline
\end{tabular}

In the study after the administration of medicine, it was obtained $94.7 \%$ of improvement in painful micturition and $100 \%$ of improvement in urinary urgency, frequency, burning micturition, tiredness, nausea and back pain. It has got statistically significant result with $p$ value 0.0001 for painful micturition, urinary urgency, frequency, burning micturition along with tiredness and nausea with $\mathrm{p}$ value 0.046 .

Table no 3 showing Effect of therapy on urine analysis (Change in mean number of Subjects)

\begin{tabular}{|l|l|l|l|l|}
\hline S No & Variables & Mean BT & Mean AT & $\begin{array}{l}\text { Percentage of } \\
\text { Improvement }\end{array}$ \\
\hline 1 & WBC & 0.9 & 0.35 & $61.1 \%$ \\
\hline 2 & Epithelial cells & 0.45 & 0.05 & $88.8 \%$ \\
\hline 3 & Nitrites & 1 & 0.1 & $90 \%$ \\
\hline 4 & Leucocyte esterase & 1 & 0.1 & $90 \%$ \\
\hline 5 & Bacteria & 1 & 0.1 & $90 \%$ \\
\hline 6 & Urine culture & 1 & 0.1 & $90 \%$ \\
\hline
\end{tabular}

Statistically significant result was obtained in WBC with (p value 0.001 ) and $61.1 \%$ improvement, epithelial cells ( $p$ value 0.005 ) and $88.8 \%$ improvement, nitrites with $p$ value $(0.0001$ ) and $90 \%$ improvement, leucocyte esterase with $\mathrm{p}$ value (0.0001) and 90\% improvement, presence of bacteria (E.coli) having $\mathrm{p}$ value (0.0001) with $90 \%$ improvement and urine culture with p value (0.0001) and 90\% improvement.

Chart no 1 showing (percentage of improvement)

\section{PERCENTAGE OF IMPROVEMENT}

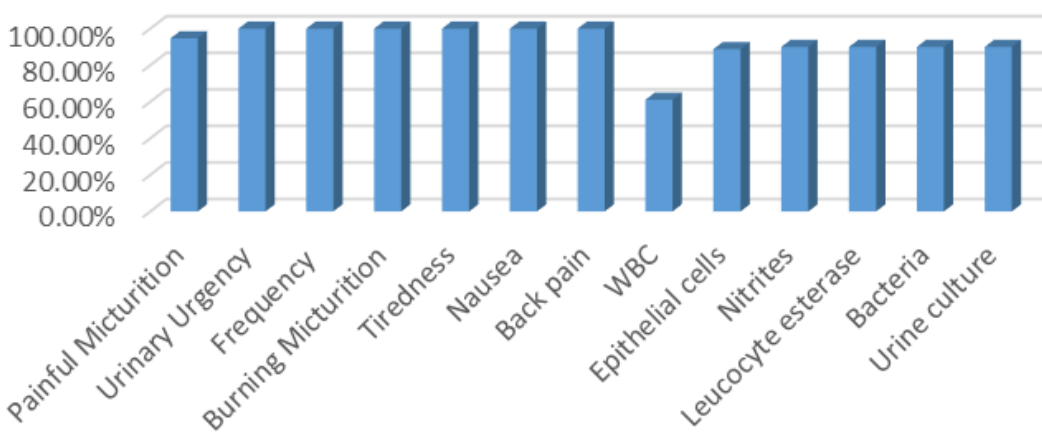

\section{Effect of Therapy}

Table no 5 Showing the Result of Wilcoxon Signed Rank Test

\begin{tabular}{|l|l|l|l|l|l|}
\hline S. NO & Parameters & Mean Rank & Sum of Ranks & Z Value & P-value \\
\hline 1 & Painful Micturition & 9.50 & 171 & -4.243 & 0.0001 \\
\hline 2 & Urinary urgency & 8.50 & 136 & -4.000 & 0.0001 \\
\hline 3 & Frequency & 10.00 & 190 & -4.359 & 0.0001 \\
\hline 4 & Burning Micturition & 7.50 & 105 & -3.742 & 0.0001 \\
\hline
\end{tabular}


Int. J. Ayur. Pharma Research, 2021;9(9):21-26

\begin{tabular}{|l|l|l|l|l|l|}
\hline 5 & Tiredness & 2.50 & 10 & -2.000 & 0.046 \\
\hline 6 & Nausea & 2.50 & 10 & -2.000 & 0.046 \\
\hline 7 & Back pain & 6.00 & 66 & -3.317 & 0.001 \\
\hline 8 & Nitrites & 9.50 & 171 & -4.243 & 0.0001 \\
\hline 9 & Leucocyte esterase & 9.50 & 171 & -4.243 & 0.0001 \\
\hline 10 & WBC & 6 & 66 & -3.317 & 0.001 \\
\hline 11 & Epithelial cells & 4.50 & 36 & -2.828 & .005 \\
\hline 12 & Presence of Bacteria in urine & 9.50 & 171 & -4.243 & 0.0001 \\
\hline 13 & Urine culture & 9.50 & 171 & -4.243 & 0.0001 \\
\hline
\end{tabular}

\section{DISCUSSION}

In the study majority of patients were having the habit of suppressing the urge of urine and taking food untimely. It was found most of the study subjects were taking pickles, fish, and curd combined in their daily meals which will produce Tridoșhakopa. With the influence of Vata, the Pitta gets localized in the Basti and results in burning micturition (Dahamutrata) and leading to Kruchramutrata. Most of the study subjects are having the habit of Mutravegadharana and usage of common toilets vitiates the Mutravahasrotas there by Apanavatakopa producing symptoms like pain over back, lower abdomen, suprapubic region and Swalpa or Muhurmuhur Mutrata. The untimely food intake leads to Tridoșhakopa producing Agnidushti associated with Vata and Pitta.

$75 \%$ of subjects were under the age group between 20-29 years. Most of them were students having the habit of suppressing the urge of urine. They used to take less amount of water and regularly used common toilet. 95\% subjects were females and it can be due to the shorter urethra in females. Sixty percent of subjects were married and the Married women are associated with more chance of having UTI. It is due to sexual intercourse, Usage of spermicides, history of UTI and not maintaining proper hygiene. The maximum number i.e., $90 \%$ were taking mixed diet. Due to the usage of Ushna, Teekshna Aharas which produce Vata Pitta kopa result in Mutravahasrotodushti. In the study 95\% had irregular appetite. Most of the subjects are having untimely food habits that can leads to Agnidushti resulting in irregular appetite. In the study $20 \%$ had previous history of UTI. This implies the recurrence of infection and it may be due to incomplete course of treatment, lack of hygiene and decreased water intake.

Among the 20 subjects enrolled for the study, majority of subjects were having the Lakshana of Vata and Pittaja Mutrakrcuhra. So due to the Nidana, Vata Pitta Pradhana Tridoșhakopa occurs and the Doșhas get localized in the Mutravahasrotas which is already invade by the uropathogens results in Paripeeda of Mutra Marga associated with symptoms like Daha, Kruchra or Muhur Muhur Mutrata.

\section{Discussion of Subjective Parameters}

In UTI the colonization of bacteria in the bladder leads to vasodilatation and leucocyte migration to the site of injury. It causes the release of inflammatory mediators like cytokines, histamines and clotting factors resulting in ulceration of bladder mucosa. This may turn to loss of bladder elasticity and subsequent pain from even mild stretching of bladder and causes painful micturition, burning sensation during urination etc. Stretch receptors in the bladder and posterior urethra subserve reflexes responsible for the urgency and frequency. The systemic release of inflammatory mediators causes back pain and tiredness $[9]$.

Urine flow and normal micturition are important for maintaining host defense mechanism to prevent UTI.[10] So, Shweta Parpați can promote diuretic action and can act as neutralizing agent. Brihatyadi Kashaya contains the herbs under the group of Laghupanchamula. Phytochemical screening of Laghupanchamula in a study showed the presence of flavanoid, tannin, and alkaloid which has been proved for its analgesic and anti-inflammatory activity against E coli.[11,12,13] The terpenoid present in Chandraprabhavați is studied for its ability to act against the infection caused by E coli..[14] Flavanoid in Chandraprabhavați is having antioxidant property $[15,16,17]$. So the presence of these constituents can help in bringing down the inflammation caused by $\mathrm{E}$ coli and thereby relieves the symptoms of UTI like painful micturition, burning Micturition.

\section{Discussion of Objective Parameters}

The Gold standard for diagnosis of UTI is significant bacterial count $\geq 10^{5}$ colony forming units (CFU) of a single bacterial strain. Nitrite produced by the enzyme called Nitrite reductase that converts urinary Nitrate to Nitrite indicates the presence of Bacteria. The detection of leucocyte esterase an enzyme specific for neutrophils and the presence of Pus cells and epithelial cells indicate the inflammatory reaction in the urinary tract.

It has got significant changes in presence of bacteria, urine culture, nitrites, leucocyte esterase after 
treatment. This can be due to the, Anti-inflammatory, Antibacterial action of phytochemical constituents of Chandraprabhavati like flavonoids, terpenoids which has been proved in an in vivo study. Brihatyadi ksheerakashayam includes the drugs which are under the group of Laghupanchamoola having the constituents like flavanoids, alkaloids tannins, and saponins etc. It possesses anti-microbial, antiinflammatory and free radical scavenging in properties. Shweta Parpati can neutralize the urine there by hindering the favourable environment for growth of bacteria.

\section{Probable Mode of Action}

Brihatyadi Kashaya contain five herbal drugs includes Brihati, Kantakari, Gokshura, Shalaparni and Prishniparni. It can be administered in the form of Ksheera, Toyapaka and Ghrutha which is indicated for Sarvamutravikara. ${ }^{[18]}$ In the present study it was given in the form of Ksheera Kashayam in which Ksheera is having Madhurarasa, Sheetaveerya, Mutrakruchra hara and Vatapittahara property [19]. In the Yoga, Gokshura is taken (Dviguneekruta) twice the quantity of all the drugs. Most of the drugs in Brihatyadi kashaya is having Madhura, Tiktarasa, Seetaveerya and Tridoșhahara property. They help in reducing the Lakshanas like Dahamutrata, Muhurmutrata and Kruchramutrata.

Chandraprabhavați mentioned by Acharya Sarangadhara is one of the potent herbo- mineral formulation. It is having wider therapeutic application in Bastigata conditions like Mutrakruchra, Mutraghata, Prameha etc, thereby indicating its Basti sodhana property. Flavanoid in Chandraprabhavați is having antioxidant property. So the presence of these constituents can help in bringing down the inflammation produced by bacteria.

Śhwētaparpați mentioned in Sidhaprayogasangraha contains mainly three drugs like Suryakshara, Sphatika and Navasadara. It is having Mutrala in action and is indicated in Mutrakruchra.

\section{CONCLUSION}

The present study reveals that, this specific treatment protocol have shown significant reduction in Nitrites, Leucocyte esterase, Bacterial count, WBC and Epithelial cells with considerable relief in symptoms of UTI.So this study has been proved that combination of Brihatyadi Ksheera Kashaya, Chandraprabhāvați and Śhwetaparpați is effective in Urinary tract infection.

\section{Acknowledgement}

Author is thankful to the Department of Kayachikitsa, Amrita school of Ayurveda for their technical support and valuable suggestions.

\section{REFERENCES}

1. Anthony S. Fauci, MD, Dan L. Longo, MD, Joseph Loscalzo, MD, PhD, Dennis L. Kasper, MD, Stephen L. Hauser, MD, J. Larry Jameson, MD, PhD, edited, Harrison's principles of internal medicine, 19th edition, McGraw Hill Education, eBook conversion by code Mantra, Version 1.0, ISBN: 978-0-07180215- 4, MHID: 0-07-180215-0, pg no.861.

2. Anthony S. Fauci, MD, Dan L. Longo, MD, Joseph Loscalzo, MD, PhD, Dennis L. Kasper, MD, Stephen L. Hauser, MD, J. Larry Jameson, MD, PhD, edited, Harrison's principles of internal medicine, 19th edition, McGraw Hill Education, eBook conversion by code Mantra, Version 1.0, ISBN: 978-0-07180215-4, MHID: 0-07- 180215-0, pg no.862

3. Y.P Munjal (ed). API Textbook of Medicine, New Delhi: Jaypee Brothers Medical Publishers (P) ltd, 9th edition, pg no1316

4. Soman N. Abrahamand Yuxuan Miao, The nature of immune responses to urinary tract infections,Nat Rev Immunol. 2015 October; 15(10): 655-663. doi:10.1038/nri3887.

5. Hari Sadashiva Sastri Paradakara, Vagbhatta's Ashtanga Hridaya with Sarvangha sundharavyakhya of Sri Arunadatta and Âyurvēda Rasāyana Tikka by Hemadri, Choukambha Orientalia, reprint edition 2015 chikitsa Sthana, sloka number 35, pg no 675

6. Hari Sadashiva Sastri Paradakara, Vagbhatta's Ashtanga Hridaya with Sarvangha sundharavyakhya of Sri Arunadatta and Āyurvēda Rasāyana Tikka by Hemadri, Choukambha Orientalia, reprint edition 2015 Sutra Sthana sloka number 25-27, pg no 69-70

7. Sarangadhara Samhita translated in English by Āyurvēda vidwan Prof K.R srikanthamurthy. Choukambha Orientalia madhyamakhanda $7^{\text {th }}$ chapter, 40-49 sloka, pg no106.

8. Sidha prayogasangraha by Yadavji Trikamji. published by vaidyanath Âyurvēda Bhavan, pg no 350-351.

9. Sonal Grover et al, Role of inflammation in bladder function and interstitial cystitis, Therapeutic advances in Urology, DOI: 10.1177

10. Clarks Professor Parveen Kumar, Dr Michael Clark, Kumar and Clarks clinical medicine 7 th edition, chapter 11, pg no 602

11. Shivani Ghildiyal et al, Anti-inflammatory activity of two classical formulations of Laghupanchamula in rats, Journal of Ayurvedic and Herbal Medicine January- March 2013.

12. N.Tamizh selvametal, Antimicrobial activity of Aragwada, Rasonadi and Gokshura on isolated urinary tract pathogens, Aryavaidyan, May -july 2008

13. Dr. Ajith. A, et al, Invitro study of Gokshura and Varuna against E.coli by urine culture and 
sensitivity wsr to pittaja mutrakruchra. IAMJ: Volume 4; Issue 07; July- 2016.

14. Suneeva S Christa, et al, Modulatory Effect of Chandraprabha Vati on Antimicrobial Peptides and Inflammatory Markers in Kidneys of Mice With Urinary Tract Infection, IJKD 2013; 7: 390

15. Weerasekera K. R. et al, Evaluation of the Effect of Ayurvedic Herbo-mineral Formulation: Chandraprabha vati on Albuminuria, American Journal of Clinical and Experimental Medicine 6 Published online December 1, 2015

16. N. Thamizh Selvametal, A comparative study on Antimicrobial activity of various fractions of Chandraprabhagutika and triphalachurnam on Urinary tract pathogens, J.D.R.A.S. Vol. XXVIII, No. 1-2, (2007) pp.31-42.

17. Weerasekera K.R. et al, Establishment quality and purity of "Chandraprabhavati" using sensory characteristics, physiochemical parameters, qualitative screening and TLC fingerprinting, International Journal of Herbal Medicine 2014; 2 (3): 26-29.

18. Hari Sadashiva Sastri Paradakara, Vagbhatta's Ashtanga Hridaya with Sarvangha sundharavyakhya of Sri Arunadatta and Āyurvēda Rasāyana Tikka by Hemadri, Choukambha Orientalia, reprint edition 2015 chikitsa Sthana sloka number 1-15, pg no 673-674

19. Hari Sadashiva Sastri Paradakara, Vagbhatta's shtanga Hridaya with Sarvanghasundharavyakhya of Sri Arunadatta and Āyurvēda Rasāyana Tikka by Hemadri, Choukambha Orientalia, reprint edition 2015 Sutra Sthana sloka number 25-27, pg no 6970

\section{Cite this article as:}

Anjana.S, Mahesh.C.Kundagol, Devipriya Soman, James Chacko. Pre and Post Test Clinical Study to Assess the Combined Effect of Brihatyadi Ksheera Kashaya, Chandraprabhavati and Shweta Parpati in Urinary Tract Infection. International Journal of Ayurveda and Pharma Research. 2021;9(9):21-26.

https://doi.org/10.47070/ijapr.v9i9.1870

Source of support: Nil, Conflict of interest: None Declared

\section{*Address for correspondence} Dr. Anjana.S

Department of Kayachikitsa (General Medicine),

Amrita School of Ayurveda, Amritapuri, Amrita Vishwa Vidyapeetham, Kerala, India Email: anjanas841@gmail.com Ph: 9526792118

Disclaimer: IJAPR is solely owned by Mahadev Publications - dedicated to publish quality research, while every effort has been taken to verify the accuracy of the content published in our Journal. IJAPR cannot accept any responsibility or liability for the articles content which are published. The views expressed in articles by our contributing authors are not necessarily those of IJAPR editor or editorial board members. 